\title{
PROTECTION AND PRESERVATION OF THE MARINE ENVIRONMENT AND MARINE SCIENTIFIC RESEARCH AT THE THIRD UNITED NATIONS CONFERENCE ON THE LAW OF THE SEA
}

\author{
JOSE Luis VALLARTA* \\ I \\ INTRODUCTION
}

After the Stockholm Conference on the Human Environment, which raised the concern of all peoples and governments about the degradation of our planet, the Third United Nations Conference on the Law of the Sea faced, among other things, the task of preparing the legal framework for the international cooperation necessary to save the oceans. The preparation of that legal framework required a prior agreement on the question of the new rights and duties of states vis a vis the new environmental situation. In other words, it was necessary to negotiate new territorial and other maritime jurisdictions of states. Such environmental legal activity was extremely complex since the new concepts of environmental maritime jurisdictions were intrinsically linked with new ideas on the field of maritime jurisdiction relating to economic exploitation of the oceans.

One of the speakers stated that, with the exception of Part XI of the Convention on the Law of the Sea, ${ }^{1}$ which deals with the area of the seabed beyond national jurisdiction, the other parts of the LOS Convention constitute a mere codification of existing international law and cannot be considered as the development of new legal rules governing the oceans. With due respect to the eminent professor who made that statement, I do not agree with it, and I intend to prove that although such a statement offers remarkable support to the position of the government of the United States of America, it is not an argument based on law.

II

\section{Marine Pollution}

The articles of the LOS Convention concerning the general rights and duties of all states to protect and preserve the marine environment clearly reflect the

Copyright (C) 1983 by Law and Contemporary Problems

* Alternate Permanent Representative of Mexico to the Organization of American States and Chairman of the informal consultation group on the item, "Protection and Preservation of the Marine Environment," at the Third United Nations Conference on the Law of the Sea.

1. Convention on the Law of the Sea, opened for signature Dec. 10, 1982. U.N. Doc. A/CONF. 6i2/122 (1982) [hereinafter cited as Convention], reprinled in 21 I.L.M. 1261 (1982). 
interest of developing countries in emphasizing the special responsibilities of industrialized nations in the field of the protection and preservation of the seas. The words "and in accordance with their capabilities," which are often used in the LOS Convention, indicate the special responsibilities of the industrialized world. The use of that concept in the LOS Convention was initially rejected by the delegations of industrialized countries on the grounds that it established "double standards": some, very strict, for the developed nations, and others, quite flexible, for developing countries. In my opinion, the provisions of the LOS Convention must not be construed as recognizing double standards but merely as emphasizing the obvious limitations of developing countries and the special duties of those who have the technology and the economic means to protect the oceans.

When dealing with specific rights and duties of states, the Conference divided the corresponding chapters of the LOS Convention in accordance with the different sources of marine pollution. The following sources were identified for the purpose of the Convention: a) land-based sources; b) pollution resulting from seabed activities within national jurisdiction; c) pollution resulting from seabed activities in the international area beyond the limits of national jurisdiction; d) pollution by dumping; e) pollution from ships; and f) pollution from and through the atmosphere. The jurisdiction of states to adopt measures to control the above-mentioned sources of pollution was also divided into what might be identified as: a) jurisdiction to make the law, including regulations and recommended practices and procedures; and b) jurisdiction to implement the law.

\section{A. Land-based Sources}

The task of spelling out the rights and duties of states in relation to the landbased sources of marine pollution was not difficult. No delegation contested the jurisdiction of each state to legislate and to implement its laws and regulations to protect the sea from pollution originating precisely in the inland territory of states. Accordingly, the provisions of the LOS Convention on this matter codified an existing agreement on the respective territorial jurisdiction of states.

\section{B. Pollution Resulting from Seabed Activities Within National Jurisdiction}

Since activities of exploration and exploitation of the seabed and its subsoil within national jurisdiction take place on the continental shelf or within the seabed of the territorial sea or the internal waters, the recognition of national jurisdiction of states to legislate and enforce their laws was also easily recognized and codified. However, the need was felt to ensure the implementation of minimum international standards for the safety of operations. To that end, the Conference achieved an international recognition that despite the existence of sovereign rights of states over the continental shelf, states have the duty to make and implement laws and rules "as effective as" the international rules and standards concerning the exploration and exploitation of the seabed within national jurisdiction. The meaning of this recognition is that states have the right to use their own means and technologies to explore and exploit the seabed and its subsoil within their respective national jurisdictions, provided that such means and technologies reach an 
internationally recognized minimum safety level. The effectiveness of this achievement will depend mainly on the ability of governments to create technical international rules and standards which will be binding upon states directly or indirectly.

Some of the LOS Convention articles concerning this source of pollution are good examples of restatements of existing international law as embodied in the 1958 Geneva Convention on the Continental Shelf; ${ }^{2}$ others represent the development of new rules of international law which will be governed by the principle res inter alios acta until those rules become so generally accepted that they may be considered customary international law. For example, if a country decides not to ratify the LOS Convention, that state will be bound by the general obligation to protect and preserve the marine environment, which, in my opinion, is a rule of jus cogens, but that state will not have the duty to make and implement laws and rules "as effective as" the international rules and standards concerning the exploration and exploitation of the seabed within national jurisdiction since that particular obligation is not recognized by customary international law.

\section{Pollution Resulting from Seabed Activities in the International Area}

Beyond the Limits of National Jurisdiction

The determination of the scope of the jurisdiction of states in the field of the protection and preservation of the marine environment from activities carried out for the exploration or exploitation of the seabed area beyond the limits of national jurisdiction was not a legal problem for the Conference. The regulation of those activities will, if matters go well, be done by the International Authority of the Seabed, which, in accordance with the new law of the sea, is the only authority with jurisdiction within the international area to authorize exploration or exploitation of the above mentioned submarine area. In my opinion, any authorization given unilaterally by a state to exploit such area will be an ultra vires act.

\section{Pollution by Dumping}

The Conference decided to consider "dumping" as an independent source of pollution despite the fact that all matters to be dumped necessarily originate from other sources of marine pollution. That decision was taken on the basis of the already existing London Convention on the Prevention of Marine Pollution by Dumping of Wastes and Other Matters. ${ }^{3}$

Since the dumping referred to in the London Convention, as well as the dumping referred to in the LOS Convention, can be done only from ships, airplanes, or platforms and other structures, the codification of the already existing jurisdiction of flag states or states of registry of aircraft was an easy task.

However, the right of coastal states to authorize dumping within their national jurisdiction was contested in the case of states having large continental shelves extending beyond the Exclusive Economic Zone. Some delegations were reluctant

2. Convention on the Continental Shelf, Apr. 29, 1958, 15 Li.S.T. 471, T.I.A.S. No. 5578.499 U.N.T.S. 311 .

3. Convention on the Prevention of Marine Pollution by Dumping. Dec. 29, 1972, 26 L.S.T. 2403. T.I.A.S. No. 8165 
to accept that specific national jurisdiction over the water column beyond the Exclusive Economic Zone. Finally, it was agreed that coastal states, even those having large continental shelves, have jurisdiction to control dumping within their Territorial Sea or Exclusive Economic Zone or onto their Continental Shelves. ${ }^{4}$ Paradoxically, one of the delegations which struggled enthusiastically against the right of coastal states to control dumping in the entire continental shelf today claims the unilateral "right" to exploit the seabed beyond the limits of its own national jurisdiction. In accordance with that reasoning, that claim also implies national jurisdiction over the water column in the totality of the oceans since the exploitation of the seabed has not been recognized by international law as one of the traditional freedoms of the high seas.

The wide acceptance of the Exclusive Economic Zone and of the jurisdiction over the continental shelf affirms that there already exists a customary international law recognizing the right of coastal states to control pollution within the national jurisdiction. However, the general character of the rule makes it impossible to determine the scope of the rights of coastal states which are not states parties to treaties dealing with that subject matter. Then, only coastal states parties to the LOS Convention will be sure of their legal rights vis a vis other states parties in the field of controlling dumping into the Exclusive Economic Zone or onto the continental shelf existing beyond the limits of the Exclusive Economic Zone. In analyzing this matter, it is necessary to bear in mind that the London Dumping Convention ${ }^{5}$ does not establish areas of maritime national jurisdiction for the purpose of controlling dumping. Also, in this case, coastal states which will not be parties to the LOS Convention will have to wait until there is clear customary international law which recognizes the right of the coastal states to control dumping within the Exclusive Economic Zone or continental shelf. Certainly, national regulations to control dumping beyond the territorial sea will be valid internally but such national legislation will not be binding erga omnes.

\section{E. Pollution from or through the Atmosphere}

Pollution from or through the atmosphere is a major environmental problem. However, its inclusion in the LOS Convention as an independent source of marine pollution was the product of a misunderstanding since the atmosphere is a vehicle and not a source of pollution. It must be hoped that that misunderstanding will be harmless for the implementation of the LOS Convention. It was impossible to avoid the absurdity of including the atmosphere as a source of marine pollution because the grave impact of pollution carried through the atmosphere compelled many delegations to press to include something about it in the LOS Convention.

\section{F. Pollution from Ships}

Pollution from ships was the real issue since it is a source that moves from one jurisdiction to another or to the high seas; consequently, it is subject to a changing

4. Convention, supra note 1, art. 216.

5. Convention on the Prevention of Marine Pollution by Dumping, supra note 3. 
legal regime. During the negotiation of this problem, governments forgot traditional divisions between groups of states, such as East and West or North and South. Those divisions were replaced by a new division: flag states having mainly shipping interests, and coastal states having either strong environmentalist groups at home or powerful fishing interests.

At the early stages of the preparatory committee that preceded the Conference, many developing countries, which at that time had already endorsed claims over 200 miles of national jurisdiction, reacted instinctively in accordance with the following rationale:

a) Coastal states have exclusive jurisdiction for the exploitation of natural resources within 200 miles.

b) Ships may pollute that area, adversely affecting its living resources.

c) Jurisdiction to legislate and implement national laws and regulations applicable to foreign vessels is convenient for coastal states.

Later, the same developing countries realized that such jurisdiction was inconvenient since industrialized nations could require, through their national laws and regulations, very strict standards for all vessels navigating their large areas of national jurisdiction. Some countries claiming territorial seas of 200 miles found themselves in the contradictory position of insisting on the right to exercise sovereignty over a territorial sea of 200 miles but denying the right of states to legislate and implement their laws in areas "under their sovereignty."

While these events were developing, some Latin American Caribbean countries adopted the Declaration of Santo Domingo ${ }^{6}$ which recognized a Patrimonial Sea in which coastal states have certain rights concerning the protection of the marine environment. As a participant in the Santo Domingo Conference on the Law of the Sea, I can confirm that when the Declaration was adopted, the governments of the Carribbean region did not express themselves on the difficult issue of the scope and the extent of the jurisdiction of the coastal state for the purpose of the protection of its Patrimonial Sea or Exclusive Economic Zone from pollution. That circumstance was more advantageous than other Latin American positions which implied excessive jurisdiction over foreign vessels within the 200 miles of national jurisdiction.

The flag states, guided by states that traditionally have been ready to give their "flags of convenience" to entities not having any link whatsoever with the country, insisted that control of the flag state for the purpose of protecting the oceans from pollution was sufficient. That position, theoretically a sensible one, was angrily rejected by some states whose shores had suffered the adverse effects of the irresponsible behavior of some masters of ships and their careless flag states.

All governments agreed that such protection from ships required uniform international rules and standards established by the competent international organization, the Intergovernmental Maritime Consultative Organization (today the International Maritime Organization). However, many delegations were still reluctant to abandon their jurisdiction to control irresponsible foreign ships within

6. Declaration of Santo Domingo, June 9, 1972, 11 I.L.M. 892. 
an area which for many states coincides with the Exclusive Economic Zone; that is, 188 nautical miles adjacent to a Territorial Sea of 12 miles.

An attempt was made to control the behavior of ships through recognition of the jurisdiction of the port state to punish a discharge violation wherever the violation had occurred. Through that system of port-state jurisdiction, coastal states will have the possibility of obtaining the cooperation of one of the next ports of call to implement international rules and standards by means of imposing fines for discharge violations. The idea was to create a legal framework linking all the ports of the world through a universal jurisdiction impossible to evade. This new concept was supported even by flag states which contemplated the "port-state jurisdiction" as a substitute for the "zonal approach" favored by coastal states. Coastal states favored universal jurisdiction and cooperation by states at their ports in order to punish discharge violations wherever they occurred, not as a substitute for the jurisdiction of the coastal state over the Exclusive Economic Zone or a zone of environmental protection, but as a complement to the zonal approach.

One of the most obvious cases of development of new rules of international law was the creation of this new universal jurisdiction identified as "port-state jurisdiction." In the near future, this new institution cannot be customary international law. Let us use an example to explain this thesis: A ship flying the flag of state A pollutes by discharging in violation of applicable international rules or standards in the middle of the high seas. Let us assume that state $\mathrm{A}$ is a party to the Convention and that the next port of call is at state $B$, which is also a party to the Convention. State $B$ will have jurisdiction to enforce the violated international rules and standards once the ship of state $A$ is voluntarily at one of its ports. State B will be able, on the basis of the LOS Convention, to fine the ship of state $A$. If one of those two states is not a party to the LOS Convention, the enforcement of the violated rule or standard will be illegal. As noted above, however, it will take many decades before acceptance is achieved through customary international law of the port-state jurisdiction.

Study of the articles in Part XII of the LOS Convention, dealing with pollution from ships, clearly indicates that the intricate network of rights and duties there established does not exist in present multilateral treaties and has not been accepted as customary international law. Thus, only through ratification of the LOS Convention will it be possible for states to enjoy the rights and to be bound by the obligations mentioned in those articles.

Coasial states supported the right of states to have supplementary legislative powers, in addition to the right to implement international rules and standards adopted by the competent international organization, when those international rules and standards did not exist or were insufficient to control pollution due to the characteristics of the region or the intensity of the maritime traffic. Flag states rejected that claim.

The Third United Nations Conference, facing these extreme positions (which were probably adopted as strategies) of flag states and coastal states, moved steadily towards a logical compromise along the following lines: 
a) States should accept the universal jurisdiction of port states to punish discharge violations of international rules and standards.

b) Ships are to be bound only by the national laws and regulations of the flag state and by the applicable international rules and standards.

c) Coastal states will have, within their Exclusive Economic Zones, the right to enforce international rules and standards applicable to foreign ships.

That scheme was accepted provided that the right of a coastal state to enforce international rules and standards would be limited to cases seriously affecting its Exclusive Economic Zone or its related interests. A careful negotiation of safeguards to prevent abuse by coastal states was also necessary.

Through the negotiations described above, the Conference on the Law of the Sea achieved a balanced Convention which recognizes certain rights of coastal states to protect the zones under their jurisdiction and, at the same time, ensures the universal and uniform character of the environmental rules and standards applicable to all ships and prevents unilateral actions by coastal states.

III

\section{Marine Scientific Research}

In accordance with the 1958 Convention on the Continental Shelf, marine scientific research has to be done with the consent of the coastal state. With that precedent, it was sensible to expect that the same regime would be acceptable for the Exclusive Economic Zone, since both areas have a very similar regime.

However, during the Third Conference on the Law of the Sea, delegations from industrialized countries made an effort to change the legal regime of marine scientific research undertaken on the continental shelf in order to have complete freedom in that field. From the point of view of industrialized countries, the freedom of marine scientific research, even within the national jurisdiction, would be a blessing for mankind as a whole. For developing countries, the benefits of marine scientific research would be achieved only if the coastal state controlled all foreign research within a national jurisdiction that would include the Exclusive Economic Zone and the continental shelf.

Since the new international regime of the seas recognizes specific sovereign rights of the coastal state for the exploration and exploitation of the natural resources within the limits of its national jurisdiction, the need was also felt to grant specific rights to the coastal state and to impose a new obligation upon the researcher. Following the example of the 1958 Convention on the Continental Shelf, the LOS Convention made it the duty of the coastal state to give its consent, in normal circumstances, to exploration and exploitation in the whole area under national jurisdiction. However, it recognized the right of the coastal state to withhold its consent if the project:
a) is of direct importance for the exploration or exploitation of natural resources;
b) implies drilling, use of explosives, or of harmful substances; or
c) implies the construction of artificial islands or structures. 
It was also accepted that coastal states have the right to withhold their consent if the information provided by the researcher is incomplete or false. The right of the coastal state to withhold its consent was denied in projects to be executed on the continental shelf beyond 200 nautical miles, unless the coastal state had concrete projects for the exploration or exploitation of that part of the continental shelf.

The developing coastal states accepted the obligation to grant their consent because the LOS Convention recognizes a series of duties of the researcher which ensure mutual benefits for the researching state and the coastal state. In accordance with the LOS Convention, all requests for the consent of the coastal state have to be made through governmental channels. Then, the information that will be given to coastal state governments, and in general the fulfillment of the obligations of the researcher, will provide information that will be of great value for the scientific communities of coastal states if coastal states are able to organize proper dissemination of the information received.

The delegations of the developed countries reluctantly accepted that, in some cases, the results of marine scientific research might be used against the legitimate interests of coastal developing countries. On the basis of that assumption, the Conference achieved a well-balanced legal framework for marine scientific research that includes provisions for the tacit consent of the coastal state in order to ensure that marine scientific research will not be delayed by inefficient bureaucratic procedures.

In relation to marine scientific research, the existing customary international law is in the process of being replaced by either conventional law of the sea through the LOS Convention or by a completely new customary international law. Before the Third United Nations Law of the Sea Conference, it was accepted that beyond the territorial waters all states and persons enjoyed freedom of marine scientific research, with the exception of the continental shelf, which was subject to the consent regime in accordance with the 1958 Convention on the Continental Shelf. The establishment of the Exclusive Economic Zone, both in the LOS Convention and through convergent national legislation, created a regime of consent applicable to that zone. The convergence of national legislation may create a new customary international law applicable erga omnes which may not grant to the researcher all the rights recognized in the LOS Convention. If this happens, scientists of states which are not parties to the LOS Convention will find enormous difficulties in their noble task. 